\title{
PEMBELAJARAN BIOLOGI BERORIENTASI LIFE SKILL UNTUK MENINGKATKAN AKTIVITAS DAN HASIL BELAJAR SISWA SMA KARTIKATAMA METRO
}

\author{
Muhfahroyin \\ Pendidikan biologi FKIP Universitas Muhammadiyah Metro \\ E-mail: muhfahroyin@yahoo.com
}

\begin{abstract}
The objective of this research are to increase the student activities and learning achievement in Biology Learning. This Research conducted using Classroom Action Research two cycles. The result of this research shows that life skills oriented biology learning contributed the increase of students' activities and their learning achievement. It can be seen from the increase of students' learning activities from $67,5 \%$ in cycle I to $91 \%$ cycle II. Contextual Teaching and Learning (CTL) approach also able to increase the student achievements. In cycle I, the average score of student is 70,53 increasing to 79,83. From this research, the researcher suggest that Contextual Teaching and Learning (CTL) approach should be applied, especially to integrate the values of IMTAQ in Biology learning and other subject.
\end{abstract}

Kata Kunci: Life Skill, Aktivitas Belajar, Hasil Belajar

Upaya untuk melaksanakan Kurikulum Tingkat Satuan Pendidikan (KTSP) sebagai kurikulum yang Berbasis Kompetensi telah dilakukan seluruh sekolah di Kota Metro. Khususnya di SMA Kartikatama diawali dengan penerapan Kurikulum 2004 dilanjutkan dengan KTSP mulai Tahun Pelajaran 2006/2007. Perubahan kurikulum yang diikuti perubahan paradigma sistem dan strategi pembelajaran mengharuskan guru banyak belajar untuk merubah paradigma teacher centered menjadi student centered. Selama ini yang dilakukan guru adalah mengajar, tetapi dengan Kurikulum 2004 guru harus menempatkan diri sebagai fasilitator yang membelajarkan siswa. Setelah KTSP diberlakukan maka guru dituntut lebih aktif, kreatif, dan inovatif dalam membelajarkan siswa (Depdiknas, 2006; Mulyasa, 2006).
Pelaksanaan kurikulum yang selalu mengalami perubahan dan baru berjalan satu tahun tersebut dinilai belum sempurna secara keseluruhan mengingat sarana dan prasarana belum sepenuhnya dimiliki sekolah tersebut. Tetapi di dalam pengalaman belajar, guru dituntut untuk dapat memberikan bekal life skills kepada siswa. Selain siswa mengusai materi pokok pada setiap kompetensi dasar, juga harus mengandung aspek life skills terkait dengan indikator pencapaian pembelajaran (Depdiknas, 2003).

Integrasi aspek life skills diasimilasikan dalam setiap kompetensi dasar mata pelajaran yang bersangkutan tanpa merubah struktur materi dan kurikulum. Dalam hal ini guru sebagai agen pembaharu dan fasilitator diharuskan mampu mengintegrasikan aspek life skills ke dalam proses pembelajaran, sehingga siswa mampu menguasai dan menuntaskan seluruh 
Kompetensi Dasar dengan tambahan bekal kacakapan hidup.

Berdasarkan observasi diperoleh hasil bahwa dalam kegiatan pembelajaran biologi masih sering hanya terpaku pada cara agar materi cepat selesai. Pada saat pembelajaran dimulai guru langsung memulai dengan sedikit menyampaikan ulasan materi sebelumnya dan mengaitkan dengan materi yang akan dipelajari. Selanjutnya adalah kegiatan ceramah dari guru tentang materi dan siswa diminta mendengarkan atau mencatat seperlunya. Siswa kemudian diskusi dan tanya jawab. Informasi yang diperoleh siswa hanya berasal dari buku paket dan dari informasi yang disampaikan oleh guru sehingga kurang tampak adanya aktivitas dari siswa yang mendukung pembelajaran.

Kondisi tersebut merupakan salah satu penyebab aktivitas siswa selama pembelajaran di kelas kurang begitu tampak. Masih banyak siswa yang tidak memperhatikan materi pelajaran, membuat gaduh kelas, mengganggu teman dan sebagainya. Pada umumnya siswa merasa cepat bosan dalam belajar, kurang mampu mengeksplorasi kemampuan, potensi dan kreativitas dirinya sendiri sehingga banyak sekali siswa yang belum mampu memenuhi KKM (Kriteria Ketuntasan Minimal) yang mengakibatkan siswa perlu menempuh remidial, bahkan persentase siswa yang nilainya di bawah KKM mencapai 18,20 \%. Informasi lain yang diperoleh dari hasil wawancara dengan guru biologi kelas XD adalah siswa belum memperoleh pembelajaran biologi yang berorientasi pada kecakapan hidup secara maksimal.

Dari sisi siswa, masih banyak siswa menganggap bahwa pelajaran biologi merupakan pelajaran yang sulit karena harus menghafal dan materi yang banyak. Guru sudah berusaha memperbaiki metode pembelajaran yang digunakan pada pelajaran biologi, tapi hasil belajar siswa pada matapelajaran biologi masih kurang. Kegiatan pembelajaran biologi pada umumnya dianggap kurang menarik sehingga aktivitas siswa juga rendah. Idealnya, pembelajaran biologi dapat digunakan untuk meningkatkan pengetahuan, keterampilan, nilai dan sikap tanggung jawab sebagai warga negara yang baik dan peduli terhadap lingkungannya. Oleh karena itu, pembelajaran biologi sebaiknya lebih ditekankan pada perolehan pengalaman langsung yang lebih bermanfaat bagi siswa salah satunya melalui penerapan pembelajaran biologi berorientasi kecakapan hidup. Pembelajaran yang berorientasi kecakapan hidup bukan hanya bertujuan untuk mencapai hasil belajar dalam aspek kognitif tetapi juga dalam aspek afektif dan psikomotorik karena diutamakan memberikan bekal life skills pada penyampaian materi. Pada pembelajaran berorientasi life skills terdapat hubungan yang sangat erat dan saling berpengaruh antara kehidupan nyata, aspek life skills, dan mata pelajaran.

Life skills atau kecakapan hidup adalah keahlian atau keterampilan yang harus dimiliki oleh setiap individu karena berguna untuk menghadapi dan mengatasi setiap problema yang dihadapi dalam menjalani kehidupan di masyarakat (Tim BBE, 2002). Kecakapan hidup dibagi menjadi empat, yaitu: 1) Kecakapan personal, mencakup kecakapan mengenal diri dan kecakapan berpikir rasional. Kecakapan kelompok ini pada dasarnya merupakan penghayatan diri sebagai makhluk Tuhan, anggota masyarakat serta sebagai warga negara yang menyadari dan mensyukuri kelebihan dan kekurangan yang dimilikinya, sekaligus menjadikannya sebagai modal dalam 
mengembangkan diri dan meningkatkan kualitas pribadi agar bermanfaat bagi lingkungan, diri dan orang lain. 2) Kecakapan Sosial, merupakan kecakapan antar personal atau sosial mencakup kecakapan komunikasi dengan empati, kecakapan bekerjasama yang berguna untuk bekal memposisikan diri sebagai makhluk sosial yang hidup bermasyarakat. 3) Kecakapan akademik, meliputi kemampuan berpikir ilmiah yang merupakan pengembangan dari kecakapan berpikir rasional. Perbedaannya adalah jika kecakapan berpikir rasional bersifat umum maka kecakapan akademik lebih bersifat keilmuan. 4) Kecakapan vokasional sering juga disebut dengan kecakapan kejuruan atau artinya kecakapan yang dikaitkan dengan bidang tertentu yang terdapat di masyarakat. Kecakapan ini bertujuan untuk memberikan pengalaman langsung kepada siswa dalam bidang keahlian tertentu untuk melakukan suatu pekerjaan.

Pembelajaran berorientasi life skills memiliki beberapa tujuan, yaitu tujuan umum dalam pembelajaran berorientasi life skills disesuaikan dengan materi pelajaran sedangkan tujuan khusus, sebagaimana menurut Tim BBE (2002) yaitu mengaktualisasikan potensi peserta didik sehingga dapat digunakan untuk memecahkan problema yang dihadapi,memberikan kesempatan kepada sekolah untuk mengembangkan pembelajaran yang fleksibel, mengoptimalkan pemanfaatan sumber daya di lingkungan. Pembelajaran berorientasi life skills dapat dilakukan untuk semua materi pelajaran di semua jenjang pendidikan dengan disesuaikan tingkat perkembangan fisiologis dan psikologis peserta didik. Pembelajaran biologi yang berorientasi life skills dapat dilakukan dengan mengintegrasikan kecakapan hidup dalam materi pelajaran. Langkah pertama yang dilakukan adalah mengidentifikasi aspek life skills yang akan dicapai melalui kegiatan pembelajaran. Langkah kedua adalah menentukan materi yang akan diajarkan dalam kegiatan pembelajaran yang dapat digunakan untuk mencapai aspek life skills yang diinginkan. Apabila identifikasi tersebut telah dilakukan, langkah selanjutnya adalah membuat rancangan pembelajaran untuk diterapkan di kelas. Kecakapan hidup yang ingin dikembangkan sebagai hasil dari proses identifikasi selanjutnya diukur hasilnya menggunakan alat evaluasi autentik sebagai hasil belajar (Tim BBE, 2002).

\section{METODE}

Penelitian ini adalah Penelitian Tindakan Kelas (PTK) yaitu suatu bentuk kajian yang bersifat reflektif oleh pelaku tindakan yang dilakukan untuk meningkatkan kemantapan rasional dari tindakan-tindakan mereka dalam melaksanakan tugas. Tim PGSM, 1999 yang dilakukan dalam dua siklus meliputi tahapan perencanaan tindakan, pelaksanaan tindakan, observasi dan refleksi yang digambarkan dalam Gambar 1.

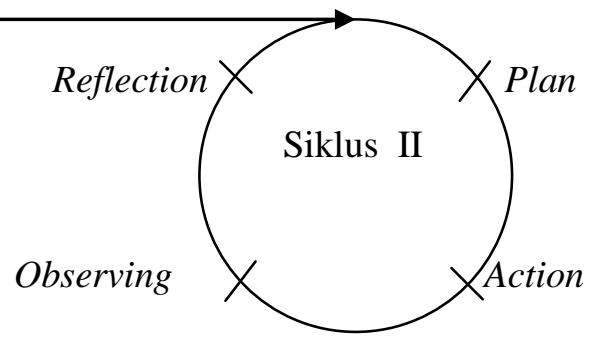


Penelitian ini dilakukan dalam dua siklus selama dua bulan yakni bulan Pebruari-Maret 2007, setiap siklus 2 kali pertemuan. Tempat penelitian di SMA Kartikatama Metro. Subjek penelitian ini adalah siswa kelas XD yang berjumlah 33 siswa.

Instrumen penelitian yang digunakan dalam penelitian ini adalah: 1) Soal tes ulangan harian untuk penilaian aspek kognitif. Tes merupakan alat ukur yang digunakan sebagai alat untuk mengetahui kemampuan kognitif siswa tentang penguasaan dan pemahaman materi (Arikunto, 2003). Soal tes diberikan setelah kegiatan pembelajaran berlangsung. 2) Lembar observasi untuk aktivitas belajar dan aspek life skills siswa beserta rubriknya yang digunakan untuk mengamati kegiatan siswa pada saat pembelajaran berlangsung. 3) Catatan lapangan untuk mengamati seluruh kegiatan penelitian yang berlangsung. Pengamatan merupakan hal penting dilakukan untuk memperoleh data yang akurat selama kegiatan penelitian berlangsung yang dilakukan oleh pengamat sebanyak 2 orang guru yang mengamati kegiatan siswa dan kondisi selama penelitian.

\section{HASIL}

\section{Siklus I}

\section{Perencanaan}

Perencanaan tindakan dilakukan berdasarkan hasil observasi yang dilanjutkan dengan refleksi awal. Kegiatan selanjutnya membuat perangkat pembelajaran berupa silabus, rencana pelaksanaan pembelajaran, dan lembar kegiatan siswa untuk siklus 1 kompetensi dasar Tingkatan Keanekaragaman Hayati di Indonesia.

\section{Pelaksanaan}

Pelaksanaan siklus 1 dilaksanakan sebanyak 2 kali pertemuan dengan waktu masing-masing pertemuan sebanyak $3 \mathrm{x}$ 45 menit. Dimulai pada tanggal 6 Pebruari 2007 yang merupakan pertemuan pertama, selanjutnya pertemuan kedua pada tanggal 13 Pebruari 2007. Pada pertemuan pertama kegiatan yang dilakukan adalah mempelajari keanekaragaman hayati tingkat gen, jenis, dan ekosistem. Sebelum dimulai kegiatan dilakukan pembagian kelompok yang sedikit memakan waktu akan tetapi untuk selanjutnya tidak diperlukan lagi karena kelompok siswa yang digunakan tetap. Siswa melakukan pengamatan di lingkungan sekitar dan bekerja dalam kelompok dengan anggota tiap kelompok ada 4 siswa yang heterogen. Pengamatan dilakukan secara berkelompok dan sesuai dengan panduan dari LKS. Pada akhir kegiatan tiap kelompok mampu menemukan informasi tentang tingkatan keanekaragaman hayati.

Selama kegiatan pengamatan siswa terlihat antusias dan bersemangat, hal ini sangat wajar mengingat selama ini kegiatan pembelajaran biologi sering hanya disampaikan melalui metode ceramah berbantuan atau diskusi dan jarang sekali dilakukan kegiatan kegiatan luar kelas. Hasil yang diperoleh dari pengamatan ini dapat terlihat dari hasil lembar observasi an hasil catatan lapangan dari observer. Hasil temuan tersebut misalnya siswa mampu mengaitkan antara konsep dan fakta bahwa terdapat perbedaan secara genetik meskipun jenis tumbuhan sama. Siswa mampu mengaitkan konsep bahwa setiap organisme memiliki perbedaan dan 
persamaan. Beberapa siswa dengan senang hati menjadi sukarelawan mencari jenis tumbuhan tertentu di lapangan sepak bola dan persawahan depan SMA Kartikatama. Siswa lain segera mencatat data pada LKS. Pada saat data diperoleh siswa berinisiatif membuat tabel perbedaan dan persamaan tumbuhan yang ditemukan. Selama kegiatan berlangsung semua aktivitas siswa direkam oleh observer menggunakan lembar observasi dan catatan lapangan.

Pertemuan kedua tanggal 13 Pebruari 2007 kegiatan pembelajaran yang dilakukan adalah presentasi dan diskusi dari tugas yang diberikan pada pertemuan I, yaitu mencari artikel dan membuat rangkuman tentang keanekaragaman hayati di Indonesia. Pada kegiatan ini dilakukan observasi tentang aktivitas siswa yang meliputi 5 komponen yaitu kbekerja sama, kemampuan menjelaskan artikel, kemampuan bertanya, kemampuan menjawab pertanyaan, dan kemampuan menanggapi jawaban teman lainnya.

Semua kelompok diusahakan maju untuk mempresentasikan artikel dan melakukan diskusi serta tanya jawab kemudian siswa dibantu guru menyimpulkan hasil diskusi berupa fakta dan konsep penting. Dari hasil nilai tes kognitif masih ada 8 siswa yang memperoleh nilai di bawah KKM yakni nilai kurang dari 65 sehingga pembelajaran pada siklus ini baru mencapai $78 \%$.

\section{Observasi}

Aktivitas siswa selama kegiatan pembelajaran ini diamati menggunakan lembar observasi tentang keaktifan siswa yang meliputi 5 komponen yaitu kemampuan bekerja sama, menjelaskan artikel, kemampuan bertanya, kemampuan menjawab pertanyaan, dan kemampuan menanggapi jawaban teman dengan masing-masing komponen memiliki kriteria yang berbeda dengan hasil sebagai berikut, aktifitas siswa pada siklus 1 masih dalam kategori sedang. Ada tiga kelompok yang memiliki aktivitas rendah disbanding kelompok lain yakni kelompok II, V, dan VII, ada tiga kelompok yang aktivitasnya sudah termasuk kategori tinggi yakni kelompok I, III dan VIII.

Aspek life skills diamati menggunakan lembar observasi, dari 20 komponen life skills ada beberapa komponen yang belum terpenuhi oleh setiap kelompok siswa pada setiap pertemuan siklus 1. Analisis perolehan komponen life skills menggunakan rumus yang sama yakni dalam bentuk persentase jadi dari masing-masing kelompok siswa diamati jumlah komponen yang dapat dicapai oleh kelompok siswa. Pada hasil siklus 1 diperoleh data pencapaian aspek life skills masing-masing kelompok termasuk dalam kategori cukup sebanyak tiga kelompok yakni kelompok I(76\%), III(73\%), VIII(78\%) sedangkan kelompok II(63\%), V(62\%), dan VII(60\%), termasuk kedalam kategori rendah.

\section{Refleksi}

Refleksi dilakukan guna perbaikan perencanaan dan pelaksanaan siklus 2 . Pada siklus 2 akan diupayakan mengurangi faktor yang menimbulkan masalah pada siklus sebelumnya dengan melibatkan masukan dari observer selama pelaksanaan siklus 1 kemudian diupayakan solusi atau jalan keluar untuk memperbaiki jalannya siklus yang selanjutnya.

Berdasarkan refleksi terdapat kekurangan dari pelaksanaan siklus 1 yaitu: 1) Guru belum tepat mengatur waktu agar semua kegiatan pembelajaran yang dilakukan sesuai dengan sintaks dalam RPP. 2) Guru kurang bisa 
menguasai dan mengelola seluruh komponen kelas sehingga masih ada kelompok siswa yang kurang diperhatikan khususnya kelompok yang menempati bangku di bagian belakang. 3) Masih banyak siswa yang belum mematuhi tata tertib dan prosedur kerja yang terdapat dalam LKS, hal ini sangat mungkin terjadi mengingat keantusiasan mereka dalam pembelajaran. 4) Siswa kurang bisa mengeksplorasi dan mengekspresikan kemampuannya memahami materi karena waktu untuk presentasi diskusi kurang. 5) Siswa masih kurang bisa bekerjasama dalam kelompok, masih banyak yang bekerja sendiri-sendiri ada yang aktif dan masih ada yang pasif. 6) Siswa cenderung kurang aktif selama kegiatan pembelajaran berlangsung, mungkin karena masih cukup asing dengan metode pembelajaran yang dilakukan.

\section{Siklus II}

Tahap perencanaan tindakan dilakukan berdasarkan hasil refleksi dari siklus 1, yaitu: 1) Menyusun RPP dan melaksanakan sesuai dengan alokasi waktu yang direncanakan agar semua kegiatan pembelajaran yang dilakukan sesuai sehingga semua kegiatan pembelajaran dapat terlaksana. 2) Guru lebih memperhatikan kegiatan siswa secara merata baik yang di depan atau belakang. 3) LKS siswa diberikan sebelum pelaksanaan kegiatan pembelajaran agar siswa dapat mematuhi tata tertib dan prosedur kerja yang terdapat dalam LKS. 4) Disediakan waktu atau kesempatan bagi siswa untuk mengeksplorasi dan mengekspresikan kemampuan dirinya dengan memberi waktu untuk presentasi-diskusi. 5) Melaksanakan metode pembelajaran yang lebih membuat siswa aktif dan bekerjasama dalam kelompok.

Hasil refleksi tersebut diakomodasi dalam penyusunan RPP untuk dilaksanakan pada siklus 2. Silabus yang dipakai tetap sama sedangkan yang dirubah adalah RPP dan LKS yakni kompetensi dasar Manfaat Keanekaragaman Hayati.

\section{PEMBAHASAN}

\section{Aktivitas Belajar Siswa}

Pada penelitian ini pembelajaran biologi yang berorientasi pada life skills dapat lebih meningkatkan aktivitas belajar siswa. Ini terlihat pada aktivitas belajar yang dilakukan oleh siswa kelas XD SMA Kartikatama Metro pada saat diberi tindakan mengalami perubahan meningkat. Pada siklus 1 yaitu siswa sudah mulai menunjukkan aktivitas belajarnya. Hal ini terjadi karena siswa sudah mulai terbiasa dengan pola pembelajaran berorientasi kecakapan hidup yang dilakukan. Selain itu, sebagaimana menurut Dewi (2006) keseimbangan antara aktivitas fisik dan mental merupakan faktor utama dalam upaya peningkatan prestasi dan kualitas pembelajaran. Sehingga dapat diindikasikan jika aktivitas belajar meningkat maka prestasi belajar siswa juga akan meningkat. Selain itu, materi yang dipelajari adalah lingkungan sekitar yang sudah dirambah setiap hari.

Hal inilah yang menyebabkan siswa cenderung aktif karena materi dan kegiatan pembelajaran yang dilakukan cukup dekat dengan keseharian siswa, sehingga melalui pembelajaran ini siswa dapat lebih merasakan manfaat dari setiap materi yang dipelajari dan akan lebih bermanfaat bagi kehidupannya. Life skills merupakan orientasi pendidikan yang mensinergikan mata pelajaran menjadi life skills yang diperlukan seseorang, di manapun ia berada, bekerja atau tidak bekerja, apapun profesinya. Life skills yaitu kemampuan dan keberanian untuk menghadapi problema kehidupan, 
kemudian secara proaktif dan kreatif, mencari dan menemukan solusi untuk mengatasinya (Depdiknas, 2003). Kemampuan siswa sebagai output dari sekolah akan siap menghadapi permasalahan kehidupan yang sebenarnya dengan bekal kecakapan hidup melalui materi pelajaran. Misalnya, siswa sadar akan selalu menjaga keanekaragaman hayati dan kelestarian lingkungan di sekitarnya agar tetap lestari karena akan memproduksi oksigen yang berguna bagi organisme lainnya.

Dari temuan itu siswa dapat mengaitkan antar konsep bahwa beranekaragam organisme akan memberikan manfaat bagi kehidupan yang semakin kompleks. Kecakapan yang diperoleh siswa sudah mencakup kecakapan berpikir rasional yaitu penghubungan antar konsep dan fakta Hafidah, 2004; Nurmaningsih, 2005). Kecakapan sosial melalui kemampuan berkerjasama dengan teman, mengemukakan pendapat dalam diskusi dan sebagainya. Kecakapan vokasional yang diperoleh siswa dengan melakukan pengamatan dan pelaporan. Dengan demikian penerapan pembelajaran biologi berorientasi life skills meningkatkan aktivitas belajar siswa kelas XD SMA Kartikatama Metro.

\section{Hasil Belajar Siswa}

Hasil belajar siswa dapat diketahui setelah diberikan tes yaitu dengan memberikan tes ulangan harian yang diberikan pada setiap akhir siklus. Hal ini bertujuan untuk memperoleh gambaran sejauh mana siswa telah menguasai kompetensi dasar seperti yang telah dikembangkan dalam silabus.

Berdasarkan nilai hasil tes di akhir materi sesudah tindakan siklus 1 , nilai tes pada siklus 1 memiliki nilai rata-rata 67,38 dengan jumlah siswa yang tuntas belajar sebanyak 25 siswa (78\%) dengan
KKM 65. Karena belum tuntas 100\% perolehan nilai hasil belajar, maka perlu dilakukan tindakan siklus 2 agar siswa lebih memahami dan mengerti materi dan bukan hanya dihafal sebagai teori.

Dalam penelitian ini, metode pembelajaran yang dipakai adalah pembelajaran kelompok kecil yang relevan dengan tujuan pendidikan yang ingin dicapai melalui pembelajaran berorientasi life skills, apalagi bila dikaitkan dengan berbagai life skills yang harus dimiliki siswa. Misalnya, dalam kecakapan berpikir rasional, siswa dituntut memiliki kecakapan menggali dan menemukan informasi, kecakapan mengolah informasi dan mengambil keputusan serta kecakapan dalam memecahkan masalah, maka dalam pembelajaran berorientasi life skills yang telah dilaksanakan dapat dipastikan bahwa siswa memiliki beberapa komponen aspek kecakapan hidup.

Siswa juga dituntut memiliki life skills yang lain misalnya kecakapan sosial, termasuk di dalamnya adalah kecakapan berkomunikasi dan bekerjasama. Dengan kegiatan pengamatan siswa mendapatkan pengalaman sosial bahwa sebagai manusia memerlukan bantuan makhluk hidup lain dalam hidupnya. Dalam hal ini terlihat peranan pembelajaran kelompok yang mampu memberikan rangsangan kepada siswa untuk aktif, kreatif dan inovatif dalam memecahkan permasalahan baik dalam konteks sosial maupun individual. Sebagaimana menurut Slavin (1995) bahwa ada 5 unsur model pembelajaran kooperatif yaitu: 1) Adanya saling ketergantungan positif antar anggota kelompok. 2)Adanya tanggung jawab perseorangan. 3) Adanya tatap muka, setiap kelompok harus diberikan kesempatan untuk bertatap muka dan berdiskusi. 4) Harus ada komunikasi antar anggota. Dalam hal ini siswa tentu harus dibekali dengan 
teknik berkomunikasi. 5) Adanya evaluasi proses kelompok, yang dijadwalkan dan dilaksanakan oleh guru. Pembelajaran biologi yang berorientasi life skills dapat menggunakan berbagai metode pembelajaran, bukan hanya menggunakan metode kerja kelompok saja. Meskipun menggunakan metode ceramah hendaknya diberikan muatan life skills yang bermanfaat bagi siswa. Karena pada dasarnya pendidikan memiliki tujuan utama yaitu agar peserta didik mampu menyelesaikan permasalahan kehidupan yang dihadapi dengan cara lebih baik dan lebih tepat. Mata pelajaran sebenarnya berfungsi untuk menjelaskan fenomena alam kehidupan sehingga lebih mudah dipahami dan lebih mudah dicarikan solusi jika ditemukan permasalahan (Tim BBE, 2002).

Berdasarkan pembelajaran biologi berorientasi life skills dapat diketahui ada peningkatan aktivitas dan prestasi belajar siswa. Secara rinci dari empat komponen kecakapan hidup yang diamati meliputi kecakapan berpikir rasional, kecakapan sosial, kecakapan akademik, dan kecakapan vokasional dapat dilihat kemampuan yang sudah dicapai siswa selama mengikuti kegiatan pembelajaran. Indikator kecakapan hidup dalam lembar observasi digunakan selama satu siklus yakni 2 pertemuan sehingga selama satu siklus pembelajaran dapat diketahui persentase pencapaian indikator kecakapan hidup oleh siswa.

Melalui kegiatan presentasi-diskusi siswa dapat mengembangkan kemampuan berkomunikasi dan bekerjasama yang termasuk kedalam komponen kecakapan sosial. Kecakapan akademik siswa dapat diperoleh dari hasil evaluasi berupa nilai tes dan pembuatan laporan praktikum siswa. Jadi hasil yang diperoleh siswa dalam kegiatan pembelajaran berupa presentasi-diskusi adalah memiliki kecakapan sosial dan kemampuan tersebut harus dikembangkan lagi, mengingat kemampuan bersosialisasi merupakan salah satu faktor penentu kesuksesan seseorang (Cloud dan John, 2003).

Kecakapan akademik identik dengan prestasi belajar, penelitian ini dilakukan pada siswa SMA sehingga aspek kecakapan akademik dapat diketahui dari prestasi belajar siswa selama kegiatan penelitian dalam dua siklus. Prestasi belajar siswa meningkat maka kecakapan akademik yang diperoleh siswa juga meningkat (Zunita, 2005). Kecakapan berpikir rasional siswa juga dapat diketahui dari hasil kerja ilmiah siswa yang termasuk ke dalam penguasaan aspek kecakapan hidup, sudah terlihat pada siklus 1 akan tetapi masih perlu ditingkatkan lagi.

Pada kecakapan berpikir rasional siswa memiliki pemikiran kritis dan peka terhadap lingkungan sekitarnya, apabila dikaitkan dengan kegiatan pembelajaran yang dilakukan pada materi keanekaragaman hayati yakni kegiatan pengamatan lapangan, siswa akan mampu mengaitkan konsep yang diperoleh dari materi secara teoritis dengan fakta bahwa keanekaragaman memberikan manfaat yang besar bagi kehidupan manusia dan makhluk hidup lainnya. Dari uraian diatas dapat diketahui melalui penelitian ini ternyata penerapan pembelajaran berorientasi life skills dapat meningkatkan hasil belajar siswa.

\section{KESIMPULAN DAN SARAN}

\section{Kesimpulan}

Kesimpulan yang diperoleh dalam penelitian ini adalah bahwa pembelajaran biologi berorientasi life skills dapat dilaksanakan untuk 
meningkatkan aktivitas belajar siswa dan hasil belajar siswa.

\section{Saran}

Agar aktivitas dan hasil belajar biologi meningkat, maka pembelajaran biologi berorientasi life skills dapat dilaksanakan dengan perencanaan dan pelaksanaan yang baik.

\section{DAFTAR RUJUKAN}

Depdiknas. 2006. Permendiknas No. 22 Tahun 2006 tentang Standar Isi. Jakarta: BSNP.

Arikunto, S. 2003. Dasar-Dasar Evaluasi Pendidikan (Edisi Revisi). Jakarta: Bumi Aksara.

Cloud, H \& John T. 2003. Boundaries, When To Say Yes, When To Say No To Take Control of Your Life. Jakarta: Grasindo

Depdiknas. 2003. Sistem Pendidikan Nasional. Undang-undang Nomor 20 Tahun 2003. Jakarta: Depdiknas.

Dewi, Wenny Tri Prasetya. 2006. Penerapan Pembelajaran Kooperatif Model STAD Untuk Meningkatkan Aktivitas dan Hasil Belajar Biologi Siswa Kelas X SMA Negeri 1 Gondangwetan Pasuruan. Skripsi tidak diterbitkan. Malang: Universitas Negeri Malang

Hafidah, R.A.J. 2004. Peningkatan Prestasi dan Motivasi Belajar Siswa Pada Mata Pelajaran Geografi Melalui Penerapan Pendidikan Berorientasi Kecakapan Hidup. Skripsi tidak diterbitkan. Malang: Universitas Negeri Malang.

Mulyasa, 2006. Kurikulum Tingkat Satuan Pendidikan. Bandung: Remaja Rosda Karya.
Nurmaningsih, I.L. 2005. Penerapan Pembelajaran Berorientasi Kecakapan Hidup (Life Skill) untuk Meningkatkan Motivasi dan Hasil Belajar Siswa Pada Mata Pelajaran Biologi Kelas I-1 dan I-2 SMAN Bluto Sumenep. Skripsi tidak diterbitkan. Malang: Universitas Negeri Malang.

Slavin, R.E. 1995. Cooperative Learning; Theory, Research, and Practice. Massachusetts: Allyn and Bacon.

Tim BBE. 2002. Kecakapan Hidup LIFE SKILL Melalui Pendidikan Berbasis Luas. Surabaya: Surabaya Intelektual Club (SIC).

Tim PGSM. 1999. Penelitian Tindakan Kelas (Classroom Action Research). Jakarta: Dirjen Dikti Departemen Pendidikan dan Kebudayaan.

Zunita, E. 2005. Upaya Peningkatan Keaktifan Dan Prestasi Belajar Biologi Melalui Penilaian Portofolio Siswa Kelas X-A SMA Darul Ulum 2 Unggulan BPPTeknologi Jombang. Skripsi tidak diterbitkan. Malang: Universitas Negeri Malang. 
